\title{
Prospective Study on Acute Poisoning Related Deaths in Menoufia Poisoning and Addiction Control Center (MPCC), Menoufia University Hospitals
} Azza Wagih Zanaty ${ }^{1}$

\author{
${ }^{1}$ Forensic Medicine and Clinical Toxicology Department, Faculty of Medicine, Menoufia University, Egypt
}

\begin{abstract}
Introduction: Acute poisoning is a common medical emergency that causes morbidity and mortality. Acute poisoning fatality is of medical, legal and social significance.

Aim of the work: The present work aimed at describing the demographic, characters of deaths due to acute poisoning (type and manner of poisoning), management and mechanism of death.

Subjects and Methods: Prospective study on deaths due to acute poisoning which admitted to MPCC through a period from 1-1-2015 to 31-12-2016. Cases were evaluated. The results were further studied by statistical tests.

Results: During the study period, 4,834 acute poisoned cases were admitted in MPCC. Among which 78 cases (1.6) \% were died. The most common age of deaths was $7-18$ years $41 \%$ followed, by age $>18-30$ years $33.3 \%$. Females surpassed males (59\%), students accounted $41 \%$ followed by farmers $23 \%$. The majority of deaths were single and from rural areas. More than fifty percent of poisoned cases were due to Aluminum phosphide followed by insecticides 25\%. Oral ingestion was the prominent method of intake $94.4 \%$. Suicidal intention was more common than accidental cases $(74.4$ $\%$ versus $25.6 \%$ ). Suicide was significantly common in females age groups (7-18) and ( $>18-30)$ years mainly in students and non- worker cases. Metabolic acidosis was significantly correlated to Aluminum phosphide and insecticides, while hypoxia was significantly associated with Dormex and corrosive poisoning. ECG changes showed arrhythmia in Aluminum phosphide poisoning. Meanwhile bradycardia was associated to dormex and insecticides poisoning. Low blood cholinesterase level was significantly present in insecticides poisoned cases. There was significant relation to cardiac arrest as a cause of death to Aluminum phosphide cases.

Conclusion and recommendation: Suicide was significantly common in females age groups (7-18) and (>18-30) years mainly in students and non- worker cases. The majority of cases were single and from rural areas. Most commonly used agents are aluminum phosphide and insecticides. Cardiac arrest was the main cause of death in aluminum phosphide poisoned cases. The mortality due to poisoning can be reduced by conducting educational programs in rural areas, restrict the availability of aluminum phosphide and insecticides, keep pesticides away from easy to use for suicide and providing needy people by poison information danger.
\end{abstract}

Keywords Poisoning, incidence, death.

\section{Introduction}

$\mathrm{P}$ oison is a substance that harms the body and life of the person due to its exposure by ingestion, injection, inhalation, or contact (Thomas et al., 2007). Agrochemicals, environmental agents or drugs are used as poisoning substances (Hempestead, 2006). Acute poisoning is a common medical emergency that causes morbidity and mortality (Flanagan and Rooney, 2002; Eddleston and Phillips, 2004). The incidence of poisoning in recent years increases due to many causes as changes in lifestyle, socioeconomic pressures, unemployment, emotional disturbances and chronic diseases (Chowdhary et al., 2007; Curtin et al., 2016; Shojaei et al., 2016).

Poisoning death refers to any fatality due to accidental, suicidal and homicidal poisoning. Statistics on poisoning fatalities are important in evaluating the health status and health care of the region (Belanger et al., 2008). Acute poisoning death is of medical, legal and social significance. It is not preventable due to many factors as patients with suicidal intention are found late after their attempt, so they received medical care too late. Furthermore, the majority of these patients used highly toxic substances to end their life (Townsend et al., 2001; Nair and Revi, 2015).

Unintentional poisoning caused nearly $71 \%$ of the estimated 346000 deaths in 2004 and this is considered preventable through strategies improving chemical safety (Prüss-Ustün and Corvalan, 2006). The 9th annual report of the National Injury Mortality Surveillance System (NIMSS) in 2007 accounts 4\% deaths due to poisoning with increase in the age group 30-34 year (www.mrc.ac.za/crime/nimss07.PDF.). World Health Organization (WHO) estimated 0.3 million people die every year from poisoning (Thundiyil 
et al., 2008). Acute pesticide poisoning attributes one of the most common causes of intentional deaths worldwide (Konradsen et al., 2007).

Prüss-Ustün et al., (2011) reported that poisoning contributes 1.2 million deaths and $1.7 \%$ of the total burden of disease in the world. In developing countries, poisoning is a major cause of burden of disease (Asadi and Afshari, 2014).

\section{Aim of the Work}

The study aims to evaluate deaths due to acute poisoning regarding demographic data, type of poison and manner of poisoning, management and mechanism of death.

\section{Subjects and Methods}

Subjects: Prospective study was conducted on all deaths due to acute poisoning which admitted to MPCC through a period from 1-1-2015 to $31-12-2016$.

Material and Methods: Informed valid consent was obtained from the parents/legal guardians of the patients underage or comatose before the study. The study was carried out in an ethical manner following guidelines set by the Ethical Committee of Faculty of Medicine, Menoufia University. Also, the permission of the authority of Menoufia Poison and addiction control center (MPCC) which follows Menoufia University hospitals was taken before the study. Confidentiality ethical constitution of the study was done. All the data of the patient were recorded as socio-demographic data (age, sex, residence and occupation), poisoning data as (type of poison, route of administration and mode of intake). Systemic examination which included respiratory, cardiovascular and central nervous system was done. Electro-Cardiography (ECG), Arterial blood gases $(\mathrm{ABG})$ and specific toxicological investigations were carried on collected blood, urine and gastric lavage samples on admission. Thin Layer Chromatography (TLC) for detection of organophosphorus and carbamates according to Clarck (1986), measurement of cholinesterase level according to Waber (1966), silver nitrate-impregnated paper test for the diagnosis of aluminum phosphide (Mital et al., 1992; Goel and Aggarwal, 2007) were done when indicated. Also, radiological investigations as Computed Tomography (CT) and Echocardiography were done when needed. Data about the patient's treatment were evaluated. Results were collected, tabulated, statistically analyzed by SPSS (statistical package for social science) version 17.0 on IBM personal computer. Qualitative data were expressed as number and percentage (No. and \%) and analyzed by applying Chi-square test. Whenever the expected values in one or more of the cells in a $2 \times 2$ tables was less than 5, Fisher Exact test was used instead. p-value $\leq 0.05$ was considered significant (Elliott and Woodward, 2007).

\section{Results}

Table (1): shows that $41 \%$ of cases were at age group 7 18 years followed by $33.3 \%$ of cases at age group $18-30$ years. Females outnumbered males $59 \%$ and $41 \%$ respectively. $41 \%$ of cases were students followed by non- workers and farmers $30.1 \%$ and $23.1 \%$ respectively. The majority of cases $89.7 \%$ were from rural areas and $74.4 \%$ were single.

Table (2): Reveals that more than fifty percent of deaths were due to aluminum phosphide poisoning, followed by $25.6 \%$ of cases were due to insecticides. Furthermore, death due to corrosive, dormex and snake bite constituted $10.3 \%, 7.7 \%$ and $2.6 \%$ respectively. The most common route of intake of poison was oral ingestion $94.9 \%$. Suicidal exposure $74.4 \%$ was the commonest mode of intake followed by accidental exposure $25.6 \%$. More than fifty percent of cases presented in less than two hours from poisoning exposure, while $33.3 \%$ and $15.4 \%$ of cases presented in $2 \mathrm{~h}-<4 \mathrm{hs}$ and $>4 \mathrm{hs}$ respectively.

Table (3): shows that all deaths in both sexes at age groups $<7$ years and $7-18$ years were due to accidental and suicidal manner of poisoning respectively. While at age group 18-30 years, $85.7 \%$ of females exposed to suicidal poisoning and males equally distributed in the same age group between accidental and suicidal poisoning $50 \%$ for each one. The relation between this age group, sex and manner of poisoning was significant as $\mathrm{P}=0.04$. There was no significant relation between age, sex and manner of poisoning in age groups $(>30-50)$ and $(>50)$ years.

Table (4): reveals that more than fifty percent of suicidal cases were students followed by $31.0 \%$ were non worker. Moreover, $50 \%$ of accidental poisoning presented in farmers followed by $30 \%$ in non-worker and $10 \%$ in each of students and workers. The relation between occupation and manner of poisoning was highly significant as $\mathrm{P}=0.001$.

Table (5): shows highly significant statistical relation between type of poison and metabolic acidosis and hypoxia as $\mathrm{p}=0.00$. All cases of aluminum phosphide and dormex poisoning had metabolic acidosis and hypoxia respectively.

Table (6) reveals that there was highly significant relation between ECG and type of poison as $(\mathrm{P}=0.000)$. The majority of arrhythmic cases $75 \%$ and tachycardia $100 \%$ were due to Aluminum phosphide (fig. 1 and 2) while $66.7 \%$ of cases with bradycardia were in dormex intoxication.

Table (7): Illustrates that there was statistical significant relation between screening toxicological tests and type of poison $(\mathrm{P}=0.003)$, as all aluminum phosphide cases were positive with silver nitrite test. Furthermore, all cases of insecticides intoxication were positive for organophosphours and carbamate poisoning and had low cholinesterase level $(\mathrm{P}=0.000)$.

Table (8): shows that highly significant statistically relation between type of poisons and radiological finding as $\mathrm{P} \leq 0$. 000. Abnormal X-ray finding (alveolar opacities) (fig., 4) was found in $75 \%$ of corrosive cases, followed by $33.3 \%$ of cases of dormex intoxication and $20 \%$ of insecticides cases. Brain edema was detected by CT scan (fig., 5) in $66.7 \%$ of dormex cases and encephalopathy presented in all snake bite cases. The majority of aluminum phosphide poisoning cases had ejection fraction $>25-<40 \%$ while $9.5 \%$ of cases had ejection fraction between $15-<25 \%$ by Echocardiography. 
Table (9): shows that there was a highly significant relation between type of poison and treatment as $\mathrm{P}<0.001$. Skin decontamination was done for all cases of snakebite and $33.3 \%$ of dormex poisoned cases. Gastrointestinal decontamination was done for $90 \%, 76.2 \%$ and $66.7 \%$ of insecticides, aluminum phosphide and dormex poisoned cases respectively. All cases of snakebite and $90 \%$ of insecticides cases were given physiological antidotes followed by $33.3 \%$ of dormex cases.

Table (10): shows that there was statistical significant relation between mechanism of death and type of poison $(\mathrm{P}=0.00)$ where, $70 \%$ of cases with cardiac arrest was due to aluminum phosphide poisoning followed by $13.3 \%$ of corrosive intoxication cases. All cases with CNS depression were due to insecticides poisoning. On the other hand cause of death due to respiratory depression was equally distributed between insecticides and dormex poisoning fifty percent for each one.

Chart (1): shows the total number of acute poisoned cases during the period of study was 4.834 and the number and percentage of deaths were 78 cases (1.6) $\%$.

Table (1): Percentage Distribution of Socio-Demographic Data of Studied Deaths Poisoned Cases.

\begin{tabular}{|l|l|l|l|}
\hline Socio-demographic data & No. & $\%$ \\
\hline Age & $<7$ & 6 & 7.7 \\
\cline { 2 - 4 } & $7-18$ & 32 & 41.0 \\
\cline { 2 - 4 } & $>18-30$ & 26 & 33.3 \\
\cline { 2 - 4 } & $>30-50$ & 8 & 10.3 \\
\cline { 2 - 4 } & $>50$ & 6 & 7.7 \\
\hline Sex & Male & 32 & 41.0 \\
\cline { 2 - 4 } & Female & 46 & 59.0 \\
\hline Occupation & Student & 32 & 41.0 \\
\cline { 2 - 4 } & Farmer & 18 & 23.1 \\
\cline { 2 - 4 } & Worker & 2 & 2.6 \\
\cline { 2 - 4 } & Driver & 2 & 2.6 \\
\cline { 2 - 4 } & Non- worker & 24 & 30.8 \\
\hline Residence & Rural & 70 & 89.7 \\
\cline { 2 - 4 } & Urban & 8 & 10.3 \\
\hline Marital Status & Unmarried & 58 & 74.4 \\
\cline { 2 - 4 } & Married & 20 & 25.6 \\
\hline NO.=78 & \multicolumn{2}{|l}{} \\
\hline
\end{tabular}

Table (2): Percentage Distribution of the Studied Deaths Poisoned Cases in Relation to History of Poisoning.

\begin{tabular}{|l|l|l|l|}
\hline History of poisoning & No. & $\%$ \\
\hline \multirow{4}{*}{ Type of poison } & Aluminum phosphide & 42 & 53.8 \\
\cline { 2 - 4 } & Insecticides & 20 & 25.6 \\
\cline { 2 - 4 } & Corrosive & 8 & 10.3 \\
\cline { 2 - 4 } & Dormex & 6 & 7.7 \\
\cline { 2 - 4 } & Snake bite & 2 & 2.6 \\
\hline Rout of intake & Oral ingestion & 74 & 94.9 \\
\cline { 2 - 4 } & Dermal & 4 & 5.1 \\
\hline Mode of intake & Accidental & 20 & 25.6 \\
\cline { 2 - 4 } & Suicidal & 58 & 74.4 \\
\hline Delay of presentation & $<2 \mathrm{~h}$ & 40 & 51.3 \\
\cline { 2 - 4 } & $2 \mathrm{~h}-<4 \mathrm{~h}$ & 26 & 33.3 \\
\cline { 2 - 4 } & $>4 \mathrm{~h}$ & 12 & 15.4 \\
\hline \multicolumn{3}{|l|}{} \\
\hline NO.=78 & \multicolumn{2}{|c}{} \\
\hline
\end{tabular}


Table (3): Statistical Analysis Fisher's Exact and Chi square $\left(\mathrm{X}^{2}\right)$ Relation of Age and Sex to Manner of Poisoning.

\begin{tabular}{|c|c|c|c|c|c|c|c|}
\hline \multirow[t]{2}{*}{ Age } & \multicolumn{2}{|c|}{ Manner of poisoning } & \multicolumn{2}{|l|}{ Sex } & \multirow[t]{2}{*}{ Total } & \multirow[t]{2}{*}{ Test of sig. } & \multirow[t]{2}{*}{ P. value } \\
\hline & & & male & female & & & \\
\hline \multirow[t]{2}{*}{$<7$} & \multirow[t]{2}{*}{ accidental } & No & 4 & 2 & 6 & \multirow[t]{2}{*}{-} & \multirow[t]{2}{*}{-} \\
\hline & & $\%$ & 100.0 & 100.0 & 100.0 & & \\
\hline \multirow[t]{2}{*}{$7-18$} & \multirow[t]{2}{*}{ Suicidal } & No & 8 & 24 & 32 & \multirow[t]{2}{*}{-} & \multirow[t]{2}{*}{-} \\
\hline & & $\%$ & 100.0 & 100.0 & 100.0 & & \\
\hline \multirow[t]{4}{*}{$>18-30$} & \multirow[t]{2}{*}{ accidental } & No & 6 & 2 & 8 & \multirow{4}{*}{$\begin{array}{l}\mathrm{X}^{2} \\
3.4\end{array}$} & \multirow[t]{4}{*}{$0.04 *$} \\
\hline & & $\%$ & 50.0 & 14.3 & 30.8 & & \\
\hline & \multirow[t]{2}{*}{ Suicidal } & No & 6 & 12 & 18 & & \\
\hline & & $\%$ & 50.0 & 85.7 & 69.2 & & \\
\hline \multirow[t]{4}{*}{$>30-50$} & \multirow[t]{2}{*}{ accidental } & No & 2 & 0 & 2 & \multirow{4}{*}{$\begin{array}{l}\text { FET } \\
2.6\end{array}$} & \multirow[t]{4}{*}{0.10} \\
\hline & & $\%$ & 50.0 & 0.0 & 25.0 & & \\
\hline & \multirow[t]{2}{*}{ Suicidal } & No & 2 & 4 & 6 & & \\
\hline & & $\%$ & 50.0 & 100.0 & 75.0 & & \\
\hline \multirow[t]{4}{*}{$>50$} & \multirow[t]{2}{*}{ accidental } & No & 4 & 0 & 4 & \multirow{4}{*}{$\begin{array}{l}\text { FET } \\
6.0\end{array}$} & \multirow[t]{4}{*}{0.07} \\
\hline & & $\%$ & 100.0 & 0.0 & 66.7 & & \\
\hline & \multirow[t]{2}{*}{ Suicidal } & No & 0 & 2 & 2 & & \\
\hline & & $\%$ & 0.0 & 100.0 & 33.0 & & \\
\hline
\end{tabular}

FET $=$ Fisher's Exact test $\chi^{2}=$ chi-square test non-significant $P$-value $>0.05$ *significant $P$-value $\leq 0.05$

Table (4): Fisher's Exact Analysis between Occupation and Manner of Poisoning among Studied Poisoned Patients.

\begin{tabular}{|c|c|c|c|c|c|c|}
\hline \multicolumn{2}{|l|}{ Occupation } & \multicolumn{2}{|c|}{ Manner of poisoning } & \multirow[t]{2}{*}{ Total } & \multirow[t]{2}{*}{ Fisher's Exact test } & \multirow[t]{2}{*}{ P. value } \\
\hline & & Accidental & Suicidal & & & \\
\hline \multirow[t]{2}{*}{ Student } & No & 2 & 30 & 32 & \multirow[t]{10}{*}{19.5} & \multirow[t]{10}{*}{$0.001 * *$} \\
\hline & $\%$ & 10.0 & 51.7 & 41.0 & & \\
\hline \multirow[t]{2}{*}{ Farmer } & No & 10 & 8 & 18 & & \\
\hline & $\%$ & 50.0 & 13.8 & 23.1 & & \\
\hline \multirow[t]{2}{*}{ Worker } & No & 2 & 0 & 2 & & \\
\hline & $\%$ & 10.0 & 0.0 & 2.6 & & \\
\hline \multirow[t]{2}{*}{ Driver } & No & 0 & 2 & 2 & & \\
\hline & $\%$ & 0.0 & 3.4 & 2.6 & & \\
\hline \multirow[t]{2}{*}{ Non worker } & No & 6 & 18 & 24 & & \\
\hline & $\%$ & 30.0 & 31.0 & 30.8 & & \\
\hline
\end{tabular}

$* * P \leq 0.001=$ highly significant

Table (5): Fisher's Exact Analysis of Metabolic Acidosis and Hypoxia with Type of Poison.

\begin{tabular}{|c|c|c|c|c|c|c|c|c|c|c|}
\hline & & & \multicolumn{5}{|l|}{ Type of poison } & \multirow{2}{*}{ Total } & \multirow{2}{*}{ FET } & \multirow{2}{*}{$\begin{array}{l}\mathrm{P} \\
\text { Value }\end{array}$} \\
\hline & & & Aluminum phosphide & Insecticides & Corrosive & Dormex & Snake bite & & & \\
\hline \multirow{4}{*}{$\begin{array}{l}\text { Metabolic } \\
\text { acidosis }\end{array}$} & Present & No & 42 & 6 & 2 & 0 & 0 & 50 & \multirow{4}{*}{60.8} & \multirow{4}{*}{$0.00 * *$} \\
\hline & & $\%$ & 100.0 & 30.0 & 25.0 & 0.0 & 0.0 & 64.1 & & \\
\hline & Absent & No & 0 & 14 & 6 & 6 & 2 & 28 & & \\
\hline & & $\%$ & 0.0 & 70.0 & 75.0 & 100.0 & 100.0 & 35.9 & & \\
\hline \multirow{4}{*}{ Нypoxia } & Present & No & 0 & 2 & 4 & 6 & 0 & 12 & \multirow{4}{*}{37.6} & \multirow{4}{*}{$0.00 * *$} \\
\hline & & $\%$ & 0.0 & 10.0 & 50.0 & 100.0 & 0.0 & 15.4 & & \\
\hline & \multirow[t]{2}{*}{ Absent } & No & 42 & 18 & 4 & 0 & 2 & 66 & & \\
\hline & & $\%$ & 100.0 & 90.0 & 50.0 & 0.0 & 100.0 & 84.6 & & \\
\hline
\end{tabular}

FET $=$ Fisher's Exact Test $\quad * * P$-value $\leq 0.001=$ highly significant 
Table (6): Chi square $\left(\mathrm{X}^{2}\right)$ Statistical Relation between ECG Findings and Type of Poisons.

\begin{tabular}{|c|c|c|c|c|c|c|c|c|c|c|c|c|}
\hline & \multicolumn{10}{|c|}{ ECG } & \multirow[t]{3}{*}{$\mathbf{X}^{2}$} & \multirow[t]{3}{*}{ p.value } \\
\hline & \multicolumn{2}{|c|}{ Normal } & \multicolumn{2}{|c|}{ Arrhythmia } & \multicolumn{2}{|c|}{ Bradycardia } & \multicolumn{2}{|c|}{ Tachycardia } & \multicolumn{2}{|c|}{ Not done } & & \\
\hline & No & $\%$ & No & $\%$ & No & $\%$ & No & $\%$ & No & $\%$ & & \\
\hline Aluminum phosphide & 4 & $66.7 \%$ & 12 & $75.0 \%$ & 0 & $0.0 \%$ & 2 & $100.0 \%$ & 24 & $50.0 \%$ & 72.8 & $0.000 * *$ \\
\hline Insecticides & 0 & $0.0 \%$ & 2 & $12.5 \%$ & 2 & $33.3 \%$ & 0 & $0.0 \%$ & 16 & $33.3 \%$ & & \\
\hline Corrosive & 2 & $33.3 \%$ & 0 & $0.0 \%$ & 0 & $0.0 \%$ & 0 & $0.0 \%$ & 6 & $12.5 \%$ & & \\
\hline Dormex & 0 & $0.0 \%$ & 0 & $0.0 \%$ & 4 & $66.7 \%$ & 0 & $0.0 \%$ & 2 & $4.2 \%$ & & \\
\hline Snake bite & 0 & $0.0 \%$ & 2 & $12.5 \%$ & 0 & $0.0 \%$ & 0 & $0.0 \%$ & 0 & $0.0 \%$ & & \\
\hline
\end{tabular}

$* * P$-value $\leq 0.001=$ highly significant

Table (7): Chi square ( $\left.\mathrm{X}^{2}\right)$ Statistical Analysis between Toxicological Tests and Type of Poison.

\begin{tabular}{|c|c|c|c|c|c|c|c|c|c|c|}
\hline \multicolumn{3}{|c|}{ Toxicological } & \multicolumn{5}{|c|}{ Type of poison } & \multirow{2}{*}{$\begin{array}{l}\text { Total } \\
16 \\
\end{array}$} & $\mathrm{X}^{2}$ & p.value \\
\hline Screening & Not done & No & $\begin{array}{l}\begin{array}{l}\text { Aluminum } \\
\text { phosphide }\end{array} \\
0\end{array}$ & $\begin{array}{l}\text { Insecticides } \\
0\end{array}$ & $\begin{array}{l}\text { Corrosive } \\
8 \\
\end{array}$ & $\begin{array}{l}\text { Dormex } \\
6\end{array}$ & $\begin{array}{l}\begin{array}{l}\text { Snake } \\
\text { bite }\end{array} \\
2\end{array}$ & & 78 & $0.003 *$ \\
\hline tests & & $\%$ & $0.0 \%$ & $0.0 \%$ & $100.0 \%$ & $100.0 \%$ & $100.0 \%$ & $20.5 \%$ & & \\
\hline & Siliver & No & 42 & 0 & 0 & 0 & 0 & 42 & & \\
\hline & $\begin{array}{l}\text { nitrate } \\
\text { positive }\end{array}$ & $\%$ & $100.0 \%$ & $0.0 \%$ & $0.0 \%$ & $0.0 \%$ & $0.0 \%$ & $53.8 \%$ & & \\
\hline & Organo- & No & 0 & 20 & 0 & 0 & 0 & 20 & & \\
\hline & $\begin{array}{l}\text { phosphorus } \\
+ \\
\text { Carabamate }\end{array}$ & $\%$ & $0.0 \%$ & $100.0 \%$ & $0.0 \%$ & $0.0 \%$ & $0.0 \%$ & $25.6 \%$ & & \\
\hline Blood & Not done & No & 14 & 0 & 8 & 4 & 2 & 28 & 47.8 & $0.000 * *$ \\
\hline cholinestrase & & $\%$ & $33.3 \%$ & $0.0 \%$ & $100.0 \%$ & $66.7 \%$ & $100.0 \%$ & $35.9 \%$ & & \\
\hline & Normal & No & 28 & 0 & 0 & 0 & 0 & 28 & & \\
\hline & level & $\%$ & $66.7 \%$ & $0.0 \%$ & $0.0 \%$ & $0.0 \%$ & $0.0 \%$ & $35.9 \%$ & & \\
\hline & Low level & No & 0 & 20 & 0 & 2 & 0 & 22 & & \\
\hline & & $\%$ & $0.0 \%$ & $100.0 \%$ & $0.0 \%$ & $33.3 \%$ & $0.0 \%$ & $28.2 \%$ & & \\
\hline
\end{tabular}

Table (8): Fisher's Exact Analysis between Radiologic Finding and Type of Poison.

\begin{tabular}{|c|c|c|c|c|c|c|c|c|c|c|}
\hline \multirow{2}{*}{\multicolumn{3}{|c|}{$\begin{array}{l}\text { Radiological } \\
\text { Investigation }\end{array}$}} & \multicolumn{5}{|c|}{ Type of poison } & \multirow[t]{3}{*}{ Total } & \multirow[t]{2}{*}{ FET } & \multirow[t]{2}{*}{$P$ value } \\
\hline & & & \multirow{2}{*}{$\begin{array}{c}\begin{array}{l}\text { Aluminum } \\
\text { phosphide }\end{array} \\
0 \\
\end{array}$} & \multirow{2}{*}{$\begin{array}{c}\text { Insecticides } \\
2 \\
\end{array}$} & \multirow{2}{*}{$\begin{array}{c}\text { Corrosive } \\
2 \\
\end{array}$} & \multirow{2}{*}{$\begin{array}{c}\text { Dormex } \\
0\end{array}$} & \multirow{2}{*}{$\begin{array}{l}\begin{array}{l}\text { Snake } \\
\text { bite }\end{array} \\
0 \\
\end{array}$} & & & \\
\hline $\mathrm{X}-$ & Normal finding & No & & & & & & & \multirow{6}{*}{42.7} & \multirow{6}{*}{$0.000 * *$} \\
\hline ray & & $\%$ & 0 & 10.0 & 25.0 & 0.0 & 0.0 & 5.1 & & \\
\hline & \multirow{2}{*}{ Abnormal finding } & No & 0 & 4 & 6 & 2 & 0 & 12 & & \\
\hline & & $\%$ & 0 & 20.0 & 75.0 & 33.3 & 0.0 & 15.4 & & \\
\hline & \multirow[t]{2}{*}{ Not done } & No & 42 & 14 & 0 & 4 & 2 & 62 & & \\
\hline & & $\%$ & 100.0 & 70.0 & 0.0 & 66.7 & 100.0 & 79.5 & & \\
\hline \multirow[t]{8}{*}{$\mathrm{CT}$} & \multirow[t]{2}{*}{ Not done } & No & 42 & 14 & 8 & 0 & 0 & 64 & \multirow{8}{*}{57.5} & \multirow{8}{*}{$0.000 * *$} \\
\hline & & $\%$ & 100.0 & 70.0 & 100.0 & 0.0 & 0.0 & 82.1 & & \\
\hline & \multirow[t]{2}{*}{ Normal } & No & 0 & 6 & 0 & 2 & 0 & 8 & & \\
\hline & & $\%$ & 0.0 & 30.0 & 0.0 & 33.3 & 0.0 & 10.1 & & \\
\hline & \multirow[t]{2}{*}{ Brain edema } & No & 0 & 0 & 0 & 4 & 0 & 4 & & \\
\hline & & $\%$ & 0.0 & 0.0 & 0.0 & 66.7 & 0.0 & 5.1 & & \\
\hline & \multirow[t]{2}{*}{ Encephalopathy } & No & 0 & 0 & 0 & 0 & 2 & 2 & & \\
\hline & & $\%$ & 0.0 & 0.0 & 0.0 & 0.0 & 100.0 & 2.6 & & \\
\hline \multirow[t]{6}{*}{ Echo } & \multirow[t]{2}{*}{ Not done } & No & 8 & 20 & 8 & 4 & 2 & 42 & \multirow{6}{*}{67.4} & \multirow{6}{*}{$0.001 * *$} \\
\hline & & $\%$ & 19.1 & 100.0 & 100.0 & 66.6 & 100.0 & 53.8 & & \\
\hline & \multirow{2}{*}{$\begin{array}{l}\text { Ejection fraction } \\
(15-25 \%)\end{array}$} & No & 4 & 0 & 0 & 2 & 0 & 6 & & \\
\hline & & $\%$ & 9.5 & 0.0 & 0.0 & 33.3 & 0.0 & 7.7 & & \\
\hline & \multirow{2}{*}{$\begin{array}{l}\text { Ejection fraction } \\
(>25--<40 \%)\end{array}$} & No & 30 & 0 & 0 & 0 & 0 & 15 & & \\
\hline & & $\%$ & 71.4 & 0.0 & 0.0 & 0.0 & 0.0 & 38.5 & & \\
\hline
\end{tabular}

Echo $=$ Echocardiography CT = Computed Tomography FET= Fisher's Exact Test

$* * P$-value $\leq 0.001=$ highly significant 
Table (9): Chi square $\left(\mathrm{X}^{2}\right)$ Statistical Analysis between Treatment and Type of Poison.

\begin{tabular}{|c|c|c|c|c|c|c|c|c|c|c|c|c|}
\hline & \multicolumn{10}{|c|}{ Type of poison } & \multirow[t]{3}{*}{$X^{2}$} & \multirow[t]{3}{*}{$\mathrm{p}$} \\
\hline Treatment & \multicolumn{2}{|c|}{$\begin{array}{c}\text { Aluminum } \\
\text { phosphide } \\
(\mathrm{n}=42)\end{array}$} & \multicolumn{2}{|c|}{$\begin{array}{l}\text { Insecticides } \\
(n=20)\end{array}$} & \multicolumn{2}{|c|}{$\begin{array}{c}\text { Corrosive } \\
(\mathrm{n}=8)\end{array}$} & \multicolumn{2}{|c|}{$\begin{array}{c}\text { Dormex } \\
(n=6)\end{array}$} & \multicolumn{2}{|c|}{$\begin{array}{l}\text { Snake bite } \\
(\mathrm{n}=2)\end{array}$} & & \\
\hline & No. & $\%$ & No. & $\%$ & No. & $\%$ & No. & $\%$ & No. & $\%$ & & \\
\hline \multicolumn{13}{|l|}{$\begin{array}{l}\text { Emergency } \\
\text { stabilization }\end{array}$} \\
\hline Not done & 0 & 0.0 & 0 & 0.0 & 0 & 0.0 & 0 & 0.0 & 0 & 0.0 & \multirow[t]{2}{*}{-} & \multirow[t]{2}{*}{-} \\
\hline Done & 42 & 100.0 & 20 & 100.0 & 8 & 100.0 & 6 & 100.0 & 2 & 100.0 & & \\
\hline \multicolumn{13}{|c|}{ Skin decontamination } \\
\hline Not done & 42 & 100.0 & 20 & 100.0 & 8 & 100.0 & 4 & 66.7 & 0 & 0.0 & \multirow[t]{2}{*}{20.725} & \multirow[t]{2}{*}{$<0.001^{{ }^{* *}}$} \\
\hline Done & 0 & 0.0 & 0 & 0.0 & 0 & 0.0 & 2 & 33.3 & 2 & 100.0 & & \\
\hline \multicolumn{13}{|l|}{$\begin{array}{l}\text { Gastrointestinal } \\
\text { decontamination }\end{array}$} \\
\hline Not done & 10 & 23.8 & 2 & 10.0 & 8 & 100.0 & 2 & 33.3 & 2 & 100.0 & \multirow[t]{2}{*}{25.397} & \multirow[t]{2}{*}{$<0.001^{* * *}$} \\
\hline Done & 32 & 76.2 & 18 & 90.0 & 0 & 0.0 & 4 & 66.7 & 0 & 0.0 & & \\
\hline \multicolumn{13}{|c|}{ Physiological antidote } \\
\hline Not given & 36 & 85.7 & 2 & 10.0 & 8 & 100.0 & 4 & 66.7 & 0 & 0.0 & \multirow[t]{2}{*}{41.836} & \multirow[t]{2}{*}{$<0.001^{* *}$} \\
\hline Given & 6 & 14.3 & 18 & 90.0 & 0 & 0.0 & 2 & 33.3 & 2 & 100.0 & & \\
\hline \multicolumn{13}{|l|}{ Supportive } \\
\hline Not done & 0 & 0.0 & 0 & 0.0 & 0 & 0.0 & 0 & 0.0 & 0 & 0.0 & \multirow[t]{2}{*}{-} & \multirow[t]{2}{*}{-} \\
\hline Done & 42 & 100.0 & 20 & 100.0 & 8 & 100.0 & 6 & 100.0 & 2 & 100.0 & & \\
\hline
\end{tabular}

$* * P$-value $\leq 0.001=$ highly significant

Table (10): Fisher's Exact Test Statistical Analysis of Type of Poison in Relation to mechanism of Death.

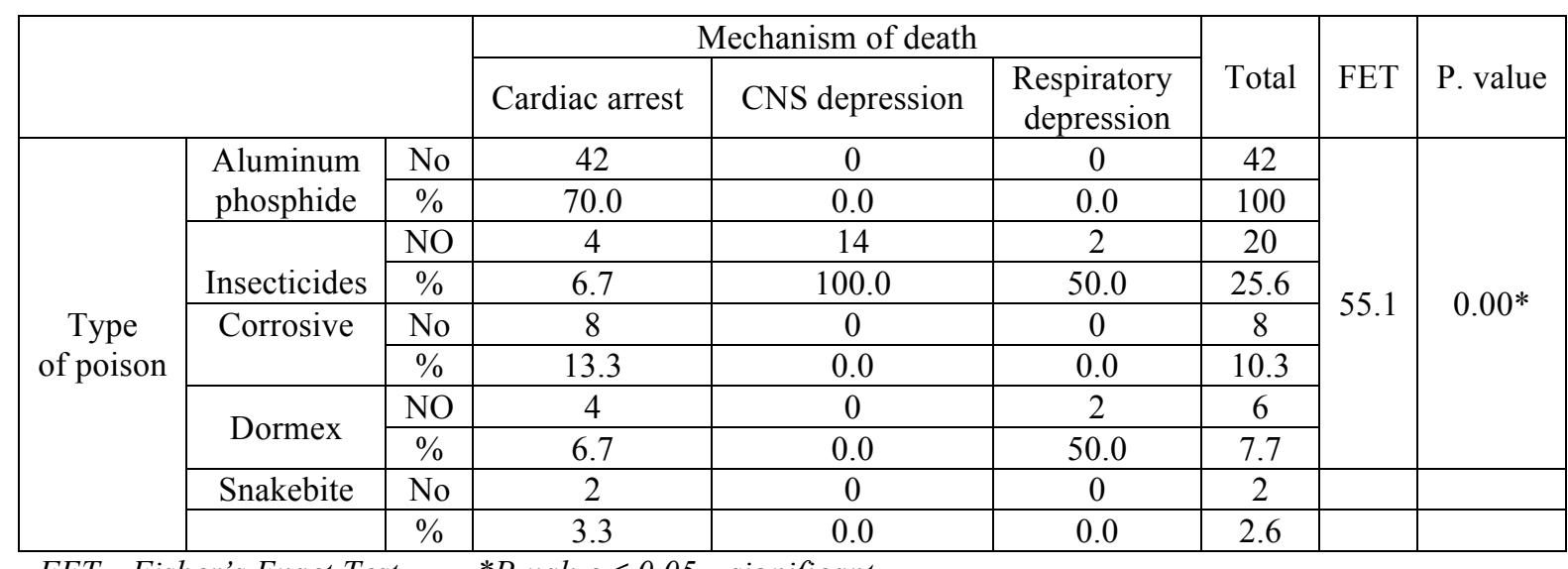

FET $=$ Fisher's Exact Test $\quad * P$-value $\leq 0.05=$ significant

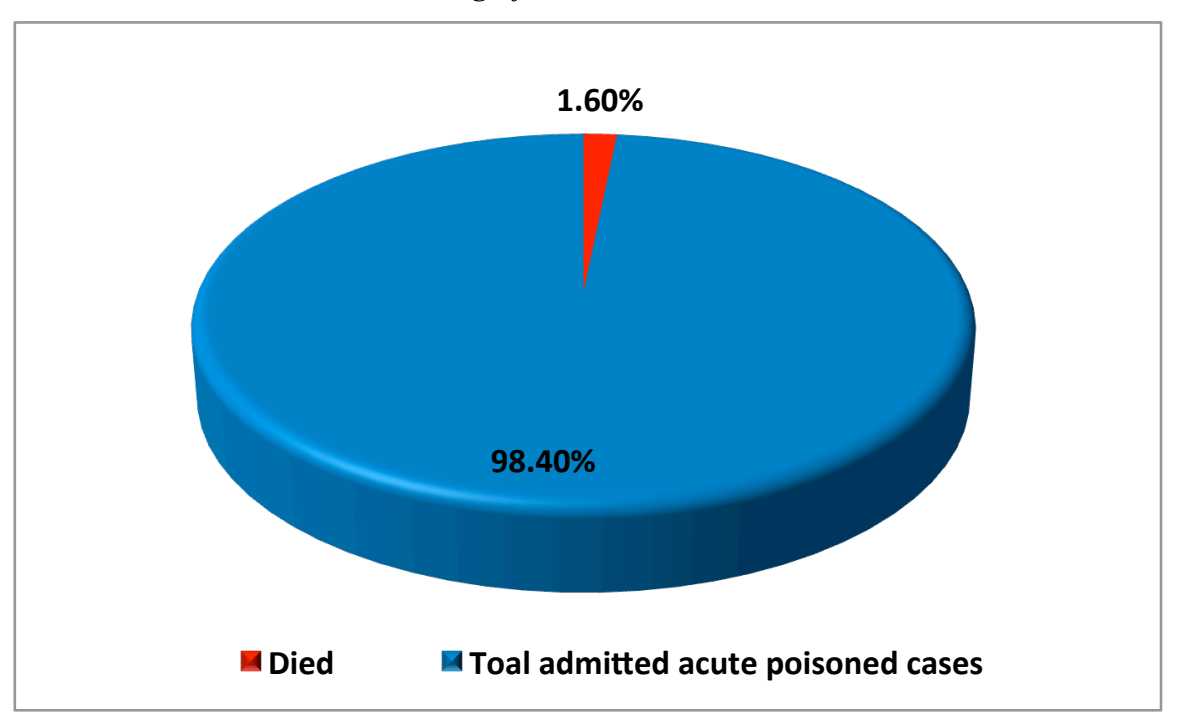

Chart (1): Percentage of Deaths among Acute Poisoned Admitted Cases. 


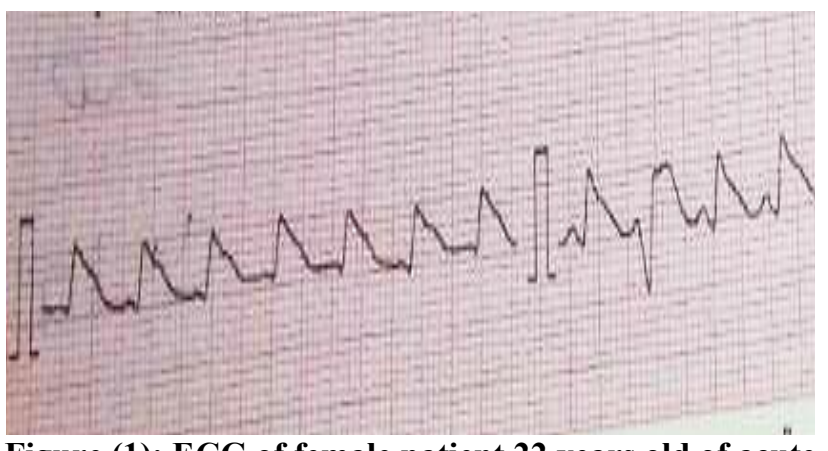

Figure (1): ECG of female patient 22 years old of acute aluminum phosphide poisoning showing elongation of S-T Segment.

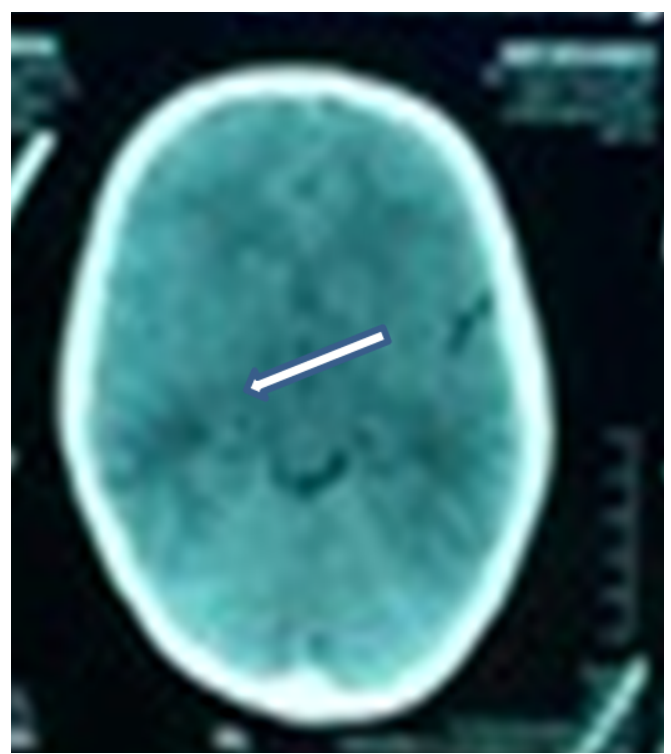

Figure (3): CT of male patient 30 years old of acute dormex poisoning showing brain Edema. (Arrow)

\section{Discussion}

Poisoning is a significant worldwide public health problem. Approximately 193.460 people died from unintentional poisoning. Of these deaths, $84 \%$ occurred in low- and middle-income countries (CDC, 2015). In this study, poisoning was the cause of death in 78 cases (1.6\%) out of 4.834 poisoned cases during the period of study. This is less than the study conducted in Iran 5.7\% (Montazeri et al., 2015), India 4.3\% (Raja and Ponnusankar, 2015) and 15\% in Sri Lanka (Darren et al., 2003). The difference may be due to differ in the nature of the poison, dose, delay time also, due to social changes.

Most common ages in deaths cases were 7-18 years followed by age of $>18-30$ years. The same results were found in the study carried by Akhgari et al., (2011) and Yartire et al., (2014) in Iran but the reverse was with other studies Kanchan and Menezes (2008) and Kanchan et al., (2010) in Southern India and Sarkar et al., (2013) in northern Bangladesh. The majority of cases in this study was females $59 \%$, the similar pattern was observed with other studies (Mostafazadeh and Farzaneh, 2013; Rhalem et al., 2013; Chala et al., 2015). In contrast poisoning fatalities are more common in

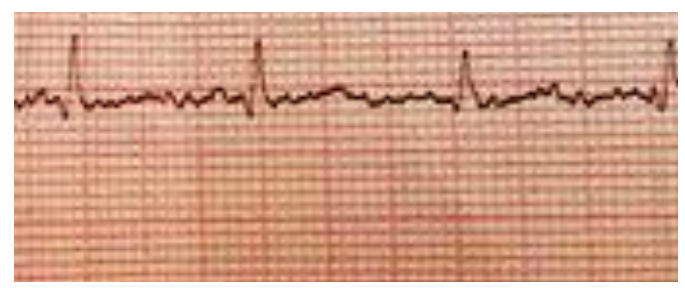

Figure (2): ECG of female patient 18 years old of acute aluminum phosphide poisoning showing atrial fibrillation.

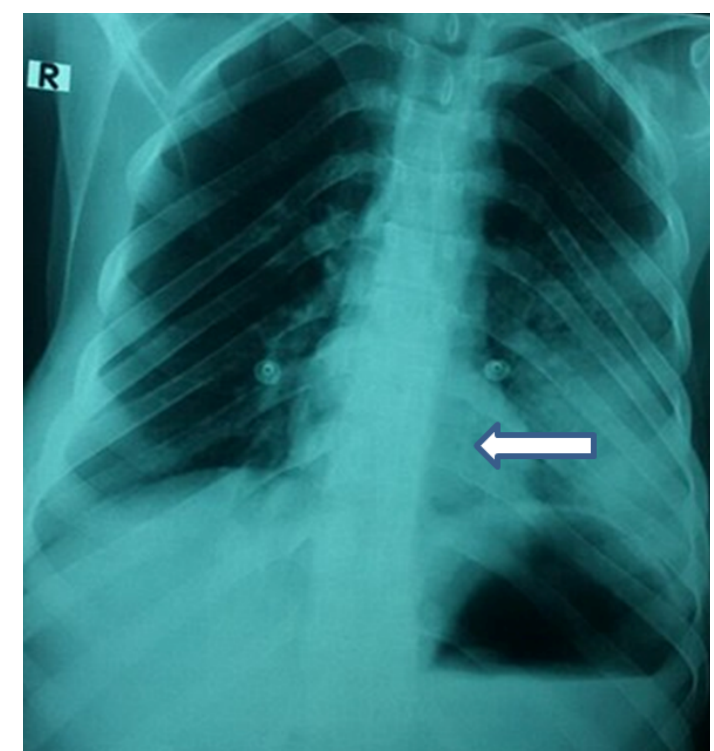

Figure (4): Plain X ray Antero-Posterior of Male Patient 40 Years Old of Acute Corrosive Ingestion Showing left side opacity (Arrow)

males than females in other studies (Peiris-John et al., 2013; Montazeri et al., 2015).

The greatest number of subjects $74.4 \%$ was unmarried persons. A finding which is similar to other reports (Najjari and Afshar, 2004; Montazeri et al., 2015). Students followed by non- workers were predominant in the present study, this is in contrast to

Radhakrishnan and Andrade (2012) and Pires et al., (2014) as, they reported that poisoning fatalities were common in unemployment. The majority of cases $89.7 \%$ were from rural areas, which could be explained by the rural nature of the Menoufia governorate.

Regarding the type of poison used, the study showed that more than fifty percent of poisoned deaths were due to aluminum phosphide followed by insecticides 25.6\%. Developing countries such as Bangladesh, India and Sri Lanka have reported increasing rates of poisoning and deaths due to pesticides (Gunnell et al., 2007; Dewan, 2014). Rout of exposure to poison was oral ingestion $94.4 \%$, this is similar to other studies (Soysal, et al., 2011; Getnet, et al., 2017). Suicide attempt occurred in $74.4 \%$ of cases. This is in agreement with the findings reported by Ali et al., (2012); Montazeri et al., (2015); Getnet, et al., 
(2017). Female patients in age groups 7-18 and $>18-30$ year accounted for the majority of committed suicide in the present study. Young females were predominant in other studies (Pokhrel et al., 2008; Senarathna et al., 2012). Moreover, suicide was significant in students and unemployed cases this is may be due to stress factors like family controversy, failure in studies, financial problems, relationship breakaway and mental conflicts (Chowdhary et al., 2007). Poisoning is a common method of committing suicide as many people believe that poison can terminate life with less pain so, highly toxic agents and higher amount of poisons are ingested (Eddleston, 2000; Zaheer et al., 2009). It is estimated that around $30 \%$ of global suicides are due to pesticide self-poisoning, most of which occur in rural agricultural areas in low- and middle-income countries (WHO, 2017).

The present study showed that more than fifty percent of poisoned cases were presented to (MPCC) in less than 2 hours. This denotes that these cases were took highly toxic substances with high doses and symptoms were developed rapidly, so they were transferred rapidly to the hospital for emergent management.

Regarding presence of metabolic acidosis and hypoxia, the study revealed that all deaths due to aluminum phosphide had metabolic acidosis. This coincides with the study of Pe'rez Navero et al., (2009) and Proudfoot (2009). Mechanism of metabolic acidosis due to aluminum phosphide is still controversy, but there is no doubt that aluminum phosphide leads to $\mathrm{H}^{+}$ ion efflux from the cell (Mehrpour et al., 2012). Hypoxia and respiratory acidosis was seen in cases of dormex intoxication. Hydrogen cyanamide is an active ingredient of dormex. It is highly toxic and adverse health effects from contact include severe irritation and ulceration of the eyes, skin, and respiratory tract (CDC, 2005).

Regarding ECG changes in the studied cases, tachycardia and cardiac arrhythmia were seen in aluminum phosphide poisoning. Gupta et al., (1998) have reported feeble heart sounds, tachy and bradycardia as cardiovascular manifestations in aluminum phosphide poisoning. Pe'rez Navero et al., (2009) reported that aluminum phosphide produces sudden vomiting, cardiac arrhythmias, shock, dyspnea and pulmonary edema. Proudfoot (2009) stated that phosphide ingestion has direct toxic effects on cardiac myocytes. The results showed that bradycardia was presented in insecticides and dormex poisoned cases. This is due to their cholinergic toxicity (Karki et al., 2004).

As regard to toxicological screening in the present study, all cases of aluminum phosphide poisoning were positive to silver nitrate test. The silver nitrate test is the common and easy to use as a screening test because of its high sensitivity (Krishan, 2011). Insecticides poisoned cases were positive for organophosphate and carbamate and had low blood cholinesterase level. Organophosphates act by inhibiting acetylcholinesterase (AChE) enzyme that is essential for the proper functioning of the nervous system as it hydrolyzes the neurotransmitter acetylcholine in the nerve synapse (Nigg and Knaak, 2000). Amgun et al., (2002) stated that serum cholinesterase level may be a useful parameter in following the prognosis of acute organophosphate poisoning.

The present study showed that alveolar opacities were seen in chest X-ray in $75 \%$ of corrosive poisoning cases due to aspiration pneumonitis. Chibishev et al., (2012) reported that patients poisoned by any corrosive substance can develop respiratory complications which depend on the type and the concentration of the corrosive substance.

Computed tomography (CT) showed brain edema and toxic encephalopathy in $66.7 \%$ of dormex intoxication and snakebite respectively. Computed tomography can detect life threatening cerebral edema owing to toxins (Simon, et al., 2004). Echocardiography showed that the majority of aluminum phosphide poisoning cases had ejection fraction $>25-<40 \%$ and less than $10 \%$ of cases had ejection fraction $15-<25 \%$. Goel and Aggarwal (2007) reported that phosphine inhibits mitochondrial cytochrome $\mathrm{C}$ oxidase which leads to pulmonary and cardiac toxicity.

As regard to treatment of cases, the study showed that skin decontamination was done for all cases of snakebite and one third of dormex poisoning as the dermal exposure was the primary route of exposure. Gastrointestinal decontamination was done for $90 \%$ of insecticides and $76.2 \%$ of aluminum phosphide poisoned cases. Eddleston et al., (2005) reported that gastric lavage is the most common form of decontamination for organophosphate poisoning. Effectiveness of gut decontamination is dependent on the duration of exposure to poison and is useful if it is done within 1-2 h. Gut decontamination should not be performed if the patient has an unprotected airway without endotracheal intubation. In aluminum phosphide intoxication, potassium permanganate $(1: 10,000)$ is used for gastric lavage through a nasogastric tube as it oxidises phosphine to nontoxic phosphate (Chyka, et al., 2005). Cases of snakebite and insecticides poisoning were given its specific physiological antidotes. Michael et al., (2006) stated that antidote reduces or reverses the effect of the poison by various mechanisms. It either prevents absorption, bind and neutralize poisons directly, antagonize the effects, or inhibit conversion of the poison to more toxic metabolite.

The present study revealed that the majority of cases $74.4 \%$ died due to cardiac arrest, where aluminum phosphide poisoning constituted $70 \%$ of them. This is similar to the study of Wahab et al., (2008) as most of the patients died within the first $24 \mathrm{~h}$ after ingestion mainly due to arrhythmia. Aluminum phosphide poisoning has a high mortality $(30-100 \%)$ if the ingested amount is more than $1.5 \mathrm{~g}$ (Hajouji Idrissi, et al., 2006).

On the other hand all cases died due to CNS depression were due to insecticides poisoning. The inhibition of cholinesterase enzyme activity leads to 
accumulation of acetylcholine at synapses, causing overstimulation and disruption of neurotransmission in both central and peripheral nervous systems (Aygun, 2004; Sataloglu, et al., 2007). Moreover, acute respiratory distress (ARDs) and respiratory depression were the cause of death in cases of insecticides and dormex poisoning. Lotti (2001) reported that during the acute cholinergic crisis, respiratory failure can occur from muscarinic effects e.g., bronchoconstriction, bronchorrhea, and alveolar edema, central depression of the respiratory center and a flaccid paralysis of muscles of respiration. Akgur et al., (2008) stated that acute respiratory distress syndrome (ARDS) has been reported in several cases of OP insecticide poisoning. It may result from pulmonary complications as aspiration or inhalation.

\section{Conclusion and Recommendations}

Poisoning was the cause of death in 78 cases $(1.6 \%)$ during the period of the study. Most common ages in deaths cases were 7-18 years followed by age of $>18-30$ years. The majority of cases were females. The greatest number of subjects was unmarried. Students followed by non- workers were predominant. They were from rural areas. More than fifty percent of poisoned deaths were due to aluminum phosphide followed by insecticides. Rout of exposure to poison was oral ingestion. Female patients accounted for the majority of committed suicide. Suicide was significant in students and unemployed cases. Deaths due to aluminum phosphide had metabolic acidosis, tachycardia and cardiac arrhythmia while hypoxia and respiratory acidosis and bradycardia were seen in cases of dormex and insecticides intoxication. Silver nitrite test was positive for aluminum phosphide poisoning while insecticides poisoned cases were positive for organophosphate and carbamate and had low blood cholinesterase level. Chest X-ray showed alveolar opacities in corrosive poisoning cases. Computed tomography (CT) showed brain edema and toxic encephalopathy in dormex and snakebite cases. The majority of aluminum phosphide poisoning cases had ejection fraction $>25-<40 \%$. Skin decontamination was done for snakebite and dormex poisoning. Gastrointestinal decontamination was done for insecticides and aluminum phosphide poisoned cases. Cases of snakebite and insecticides poisoning were given its specific physiological antidotes. The majority of aluminum phosphide cases died due to cardiac arrest. Cases died due to CNS depression were due to insecticides poisoning. Moreover, acute respiratory distress (ARDs) and respiratory depression were caused death in cases of insecticides and dormex poisoning. Health education in rural areas for hazards of pesticides should be done. Restrict the availability and usage of aluminum phosphide and aware about its toxicity. Provide standard treatment protocols for management of aluminum phosphide as no effective antidotes are available. Provide access to educational programs about cultural and religious beliefs that discourage suicide and support self -preservation.

\section{References}

Akgur S, Veral A and Ege B (2008): Adult respiratory distress syndrome in human organophosphate poisoning cases. Toxicol. Environ. Chem. 90:493-499.

Akhgari M, Jokar F and Etemadi A (2011): Drug related deaths in Tehran, Iran: toxicological, death and crime scene investigations. Iran J. Toxicol.5:402-409.

Ali P, Anwer A and Bashir B (2012): Clinical pattern and outcome of organophosphorus poisoning. JLUMHS.11(1):15-18.

Amgun D, Doganay Z, Altintop L et al., (2002): Serum acetylcholineesterase and prognosis of acute organophosphate poisoning. J. Toxicol.Clin. 40 (7):903-910.

Asadi R and Afshari R (2014): Applying Global Burden of Diseases in Medical Toxicology. Asia Pac J Med Toxicol. 3 (1): 1-1.

Aygun D (2004): Diagnosis in an acute organophosphate poisoning: report of three interesting cases and review of the literature. Eur. J. Emerg. Med. 11: 55-58.

Belanger F, Ung AB and Falzon A (2008): Poisoningrelated deaths in an enlarged European Union. Saint-Maurice, Switzerland: Institut de Veille Sanitaire. 26;53(11): 233-238.

Centers for Disease Control and Prevention (CDC) (2005): Update: hydrogen cyanamide-related illnesses--Italy, 2002-2004. MMWR Morb Mortal Wkly Rep. Apr 29;54(16):405-408.

Centers for Disease Control and Prevention (CDC) (2015): Morbidity and Mortality Weekly Report, "Suicide Trends Among Persons Aged 10-24 Years-United States, 19942012,"accessed

at www.cdc.gov/mmwr/pdf/wk/mm6408.pdf, on Jan. 27, 2016.

Chala TS, Gebramariam H and Hussen M (2015): TwoYear Epidemiologic Pattern of Acute Pharmaceutical and Chemical Poisoning Cases Admitted to Adama Hospital Medical College, Adama, Ethiopia. Asia Pac. J. Med. Toxicol. 4:106-111.

Chibishev A, Pareska Z, Chibisheva V et al., (2012): Clinical and epidemiological features of acute corrosive poisonings. Med. Arh. 66(3 Suppl 1):11-15.

Chowdhary AN, Banerjee S, Brahma A et al., (2007): Pesticide poisoning in nonfatal, deliberate selfharm: A public health issue. Indian J. Psychiatry. 49:117-120.

Chyka PA, Seger D, Krenzelok EP et al., (2005): American Academy of Clinical Toxicology and European Association of Poison Centres and Clinical Toxicologists.Position paper: Single dose activated charcoal. Clin. Toxicol. (Phila). 43:61-87.

Clarck M (1986): Isolation And Identification Of Drug "Hospital, Toxicology \& Drug Abuse" In Pharmaceutical Body Fluids and Post-Modem 
Material $2^{\text {nd }}$ Edit, London. The Pharmaceutical Press.

Curtin SC, Warner $M$ and Hedegaard H (2016): Increase in Suicide in the United States, 19992014. NCHS. Data Brief. (241):1-8.

Darren M, Roberts I, Ayanthi K et al., (2003): Influence of pesticide regulation on acute poisoning deaths in Sri Lanka. Bulletin of the World Health Organization, 81 (11).

Dewan G (2014): Analysis of Recent Situation of Pesticide Poisoning in Bangladesh: Is There a Proper Estimate? Asia Pac. J. Med. Toxicol. 3:76-83.

Eddleston M (2000): Patterns and problems of deliberate self-poisoning in the developing world. QJM. 93:715-731.

Eddleston M and Phillips MR (2004): Self poisoning with pesticides. BMJ. 328:42-44.

Eddleston M, Singh S and Buckley N (2005): Organophosphorus poisoning (acute) Clin.Evid. 13:1744-1755.

Elliott A and Woodward W (2007): SPSS (Statistical package of the social sciences, SAGE puplications. California, London and New Delhi, printed in USA.

Flanagan RJ and Rooney C (2002): Recording Acute Poisoning Deaths. Forensic Science International.128:3-19.

Getnet MA, Asegedech TW, Elizabeth L et al., (2017): Poisoning cases and their management in emergency centres of government hospitals in northwest Ethiopia. African Journal of Emergency Medicine. 7: 74-78.

Goel A and Aggarwal P (2007): Pesticide poisoning, Natl. Med. J. India. 20:182-191.

Gunnell D, Eddleston M, Phillips MR et al., (2007): The global distribution of fatal pesticide selfpoisoning: systematic review. BMC Public Health. 7:357.

Gupta MS, Malik A and Sharma VK (1995): Cardiovascular manifestations in aluminium phosphide poisoning with special reference to echocardiographic changes, J. Assoc. Physicians India. 43: 773-780.

Hajouji M, Oualili L, Abidi K et al., (2006): Severity factors of aluminum phosphide poisoning (phostoxin). Ann. Fr. Anesth. Reanim. 25:382385.

Hempestead K. (2006): Manner of death and circumstances in fatal poisoning: Evidence from New Jersey. Inj. Prev.12:44.

Kanchan T and Menezes RG (2008): Suicidal poisoning in Southern India: Gender differences. J. Forensic Leg. Med. 15:7-14.

Kanchan T, Menezes RG, Kumar TS et al., (2010): Toxico-epidemiology of fatal poisonings in Southern India. J Forensic Leg Med. ;17:344347.

Karki P, Ansari JA, Bhandary S (2004): Cardiac and electrocardiographical manifestations of acute organophosphate poisoning. Singapore Med. J. 45:385-389.
Konradsen F, Dawson AH, Eddleston M et al., (2007): Pesticide self-poisoning: thinking outside the box. Lancet. 369:169-170.

Krishan V (2011): Textbook of Forensic Medicine \& Toxicology: Principles \& Practice $5^{\text {th }}$ ed., B. I. Churchill Livingstone Pvt. Ltd. New Delhi Section II. Ch 14.

Lotti M (2001): Clinical toxicology of anticholinesterase agents in humans. Handb Pesticide Toxicol. 2:1043-1085.

Mehrpour O, Jafarzadeh M and Abdollahi M (2012): A systematic review of aluminum phosphide poisoning. Arh. Hig. Rada. Toksikol.63:61-73.

Michael JB, Richard M and Schwart Z (2006): General approach to drug intoxication in adults, available online at http:/www.uptodate.com/patients/content,topic. do.

Mital HS, Mehrotra TN, Dwivedi KK et al., (1992): A study of aluminum phosphide poisoning with special reference to its spot diagnosis by silver nitrate test. J. Assoc. Physicians India. 40:473474.

Montazeri M, Najafi N, Azarpira N et al., (2015): Investigation of Lethal Poisonings among Dead Bodies Referred to Regional Office of Iranian Legal Medicine Organization in Shiraz. Asia Pac. J. Med. Toxicol. 4:151-155.

Mostafazadeh B and Farzaneh E (2013): Risks and risk factors of repeated suicidal attempt: Study on unconscious poisoned patients. Asia Pac. J. Med. Toxicol. 2:28-31.

Nair PK and Revi NG (2015): One-Year Study on Pattern of Acute Pharmaceutical and Chemical Poisoning Cases Admitted to a Tertiary Care Hospital in Thrissur, India. Asia Pac. J. Med. Toxicol. 4:79-82.

Najjari F and Afshar M (2004): Deaths Due to Poisoning Referred to Legal Medicine Organization of Iran. Razi. J. Med. Sci. 11:309316.

Nigg HN and Knaak JB (2000): Blood cholinesterase as human biomarkers of organophosphorus pesticide exposure. Rev. Environ. Contam. Toxicol. 163:29-111.

Pe' rez Navero JL, de la Rosa I., Ibarra MA et al., (2009): Fatal poisoning by accidental inhalation of aluminum phosphide, Ann. Pediatr. (Barc). 71: 427-431.

Peiris-John R, Kool B and Ameratunga S. (2013): Fatalities and hospitalisations due to acute poisoning among New Zealand adults. Internal Medicine Journal (C) Royal Australasian College of Physicians. 14:273-281.

Pires MC, Silva TP, Passos MP et al., (2014): Risk factors of suicide attempts by poisoning: review. Trends Psychiatry Psychother. 36:6374.

Pokhrel D, Pant S and Pradhan A (2008): A comparative retrospective study of poisoning cases in central, zonal and district hospitals. 
Kathmandu Univ. J. Sci. Eng. Technol. 1(5):40-48.

Proudfoot AT (2009): Aluminum and zinc phosphide poisoning, Clin. Toxicol. 47: 89-100.

Prüss-Ustün A and Corvalan C (2006): Preventing Disease through Healthy Environments: Towards An Estimate of the Environmental Burden of Disease. Geneva: World Health Organization.

Prüss-Ustün A, Vickers C, Haefliger P et al., (2011): Knowns and unknowns on burden of disease due to chemicals: a systematic review. Environ. Health. 10: 9-24.

Radhakrishnan R and Andrade C (2012): Suicide: An Indian perspective. Indian J. Psychiatry. 54:304319.

Raja TH and Ponnusankar S (2015): Toxicoepidemiology of acute poisoning cases in a secondary care hospital in rural South India: A five-year analysis. J. Postgrad. Med. 61(3): 159-162.

Rhalem N, Aghandous R, Chaoui H et al., (2013): Role of the poison control centre of Morocco in the improvement of public health. Asia Pac. J. Med. Toxicol. 2:82-86.

Sarkar D, Shaheduzzaman M, Hossain MI et al., (2013): Spectrum of acute pharmaceutical and chemical poisoning in northern Bangladesh. Asia Pac. J. Med. Toxicol. 2:1-4.

Sataloglu N, Aydin B and Turla A (2007): Pesticide poisoning. Kor. Hek. 6:169-174.

Senarathna L, Jayamanna SF and Kelly PJ (2012): Changing epidemiologic patterns of deliberate self- poisoning in a rural district of Sri Lanka. BMC Public Health. 12: 593.

Shojaei A, Moradi S, Alaeddini F et al., (2016): Evaluating the temporal trend of completed suicides referred to the Iranian Forensic Medicine Organization during 2006-2010. J. Forensic Leg. Med. 39:104-108.

Simon MW, Andrew B and Mark CB (2004): Over dose poisoning and drug abuse in Intensive care medicine. $2^{\text {nd }}$ ed., Churchil Livingstone, New York. pp 190-202.

Soysal, D, Karakuş V and Soysal A (2011): Evaluation of Cases with Acute Organophosphate Pesticide Poisoning Presenting at a Tertiary Training Hospital Emergency Department:Intoxication or Suicide? JAEM: 156-160.

Thomas WF, John HD and Willium RH (2007): Stedman's Medical Dictonery. $28^{\text {th }}$ ed., Lippincott William and Wilkins, New York. pp. 2004.

Thundiyil JG, Stober J, Besbelli N and Pronczuk J (2008): Acute pesticide poisoning: a proposed classification tool. Bull World Health Organ. 86:205-209.

Townsend E, Hawton K, Harriss L et al., (2001): Substances used in deliberate self-poisoning 1985-1997: trends and associations with age, gender, repetition and suicide intent. Soc. Psychiatry Psychiatr. Epidemiol. 36:228-234.

Waber H, Stsch M and Wschr MD (1966): Choliesterase Kinetic Clometeric Method. 91:1927.

Wahab A, Zaheer MS, Wahab S et al., (2008): Acute aluminum phosphide poisoning: An update. Hong Kong J. Emerg. Med. 15:152155.

World Health Organization (WHO) (2017): Suicide.www.who.int/mediacentre/factsheets.

www.mrc.ac.za/crime/nimss07.PDF. A profile of fatal injuries in South Africa 2007: MRC-UNISA Crime, Violence and Injury Lead Programme.

Yartire H, Hashemian AH and Saleh E (2014): A View to Mortality Due to Poisoning Cases in Forensics Center of Kermanshah in 2006-2012. Adv. Biol. Res. 8:157-161.

Zaheer MS, Aslam M and Gupta V (2009): Profile of poisoning cases, at a north Indian tertiary care hospital. Health Popul. Perspect. 32(4):176183. 


$$
\text { الملخص العربي }
$$

\section{دراسة مستقبلية علي الوفيات المتعلقة بالتسمِفِ الحاد في مركز السموم وعلاج الإدمان مستشفيأث جامثغة المنوفية}

\section{عزة وجيه زناتي 1}

المقدمة: بعتبر التسمم الحاد من الطو ارىء الثنائعة والتى تسبب المرض و الوفاة.

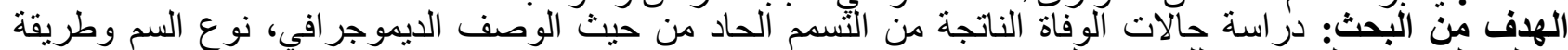

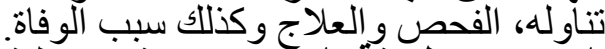

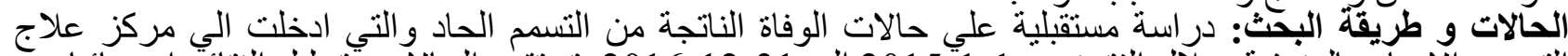

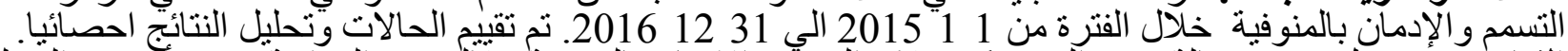

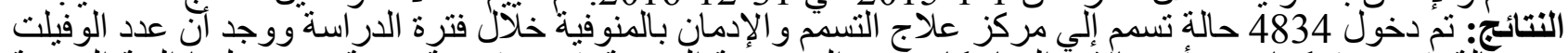

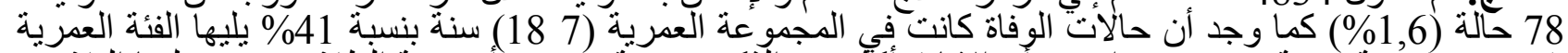

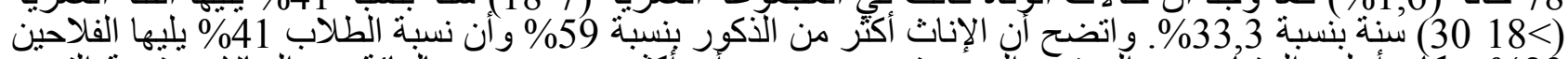

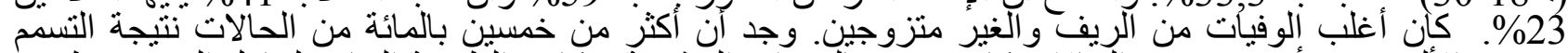

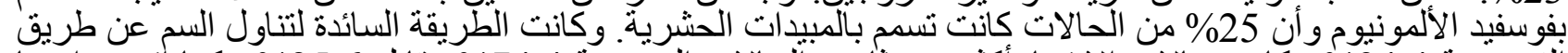

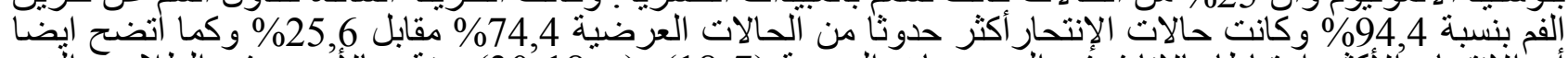

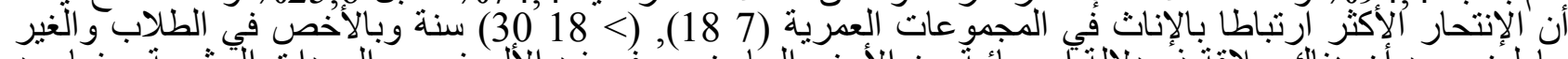

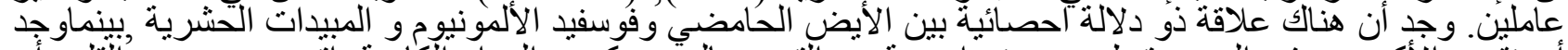

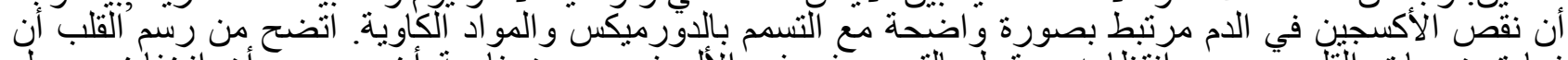

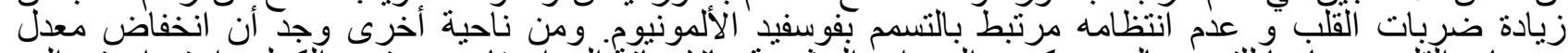

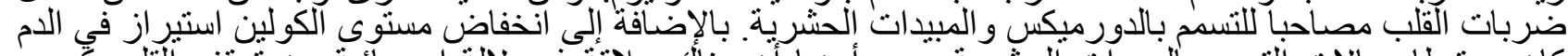

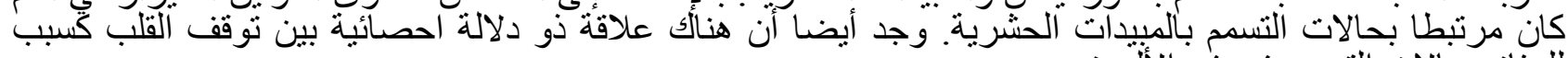

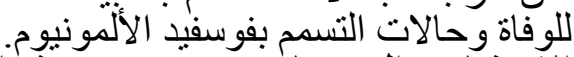

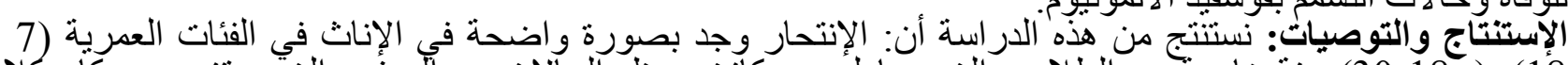

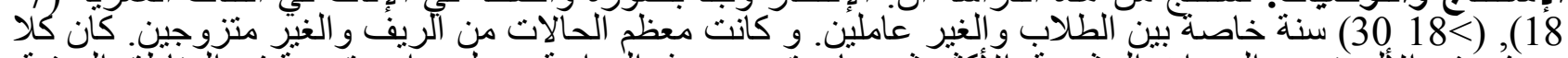

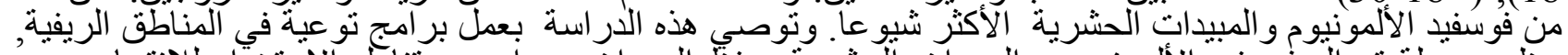

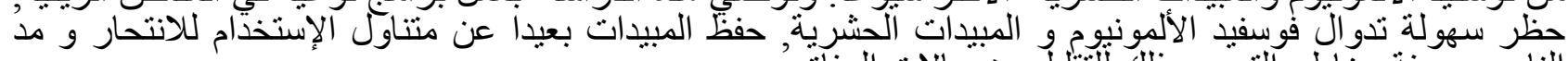

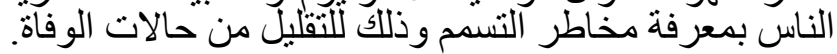

